\title{
Konfrontace diagnózy z počátku 90. let s dnešním stavem pedagogického výzkumu
}

\author{
Stanislav Štech
}

Univerzita Karlova, Pedagogická fakulta, Katedra psychologie

Když se před 20 lety konala 1 . konference čerstvě založené České asociace pedagogického výzkumu (ČAPV), zvolil jsem pro své vystoupení poněkud troufalý tón hodnocení stavu pedagogicko-psychologického výzkumu na samém počátku „nové éry“ (Pedagogicko-psychologický výzkum: nástroj normativismu, nebo zprostredkovatel společné reči?). Neberte, prosím, jako projev narcismu skutečnost, že se po dvaceti letech k tomuto textu vrátím, abych porovnal své tehdejší hodnocení, obavy a varování s dnešním stavem věcí. Je to jeden $\mathrm{z}$ možných způsobů, jak se ohlédnout za cestou, kterou pedagogický výzkum i ČAPV urazily.

Leitmotivem mého tehdejšího hodnocení bylo konstatování, že nám chybí důkladná reflexe stavu naší školy, vzdělávání i pedagogického výzkumu. V prvních letech po velké politické změně jako by všichni věděli, že se musí reformovat, i když nevěděli přesně proč a v čem. Tato absence měla podle mého soudu dvě příčiny:

1. Jednak nepřesné či spíše ideologicky podbarvené odsuzování všech výsledků školního vzdělávání i jeho dosavadního zkoumání před rokem 1989. Bylo výsledkem metodologicky chybného postoje, který francouzští historiografové nazývají iluze „velkého zlomu“ nebo „slavného předvečera". Uvedený metodologický postoj navozuje tendenci vidět téměř ve všem diskontinuitu, resp. nový začátek z bodu nula, a ignorovat kontinuitu. Projevil se v jakoby samozřejmém ignorování skutečné podoby scholarizace za předchozího režimu. Nikdy se nám nepodařilo zaplnit mezeru představovanou absencí bilanční analýzy nedávné minulosti. Ani kvalitní bilanční příspěvky v Pedagogice (4/2000) k padesátému výročí časopisu ji nezaplnily, protože opakované výzvy k věcnému a systematickému zhodnocení období socialistické pedagogiky nebyly vyslyšeny. Domnívám se, že důsledky cítíme dodnes. Klišé o „tereziánské škole“ a učitelích jako „nacpávačích dětských hlav neznajících nic než dril“ nebyla nikdy explicitně empiricky potvrzena nebo vyvrácena. Stále tak otravují veřejné mínění - a seriózní pedagogický výzkum k těmto záležitostem mlčí. 
Ideologicky motivovaná paušální dehonestace tzv. socialistické školy přinesla trpké ovoce. Škola je v mnoha textech a přístupech (nejen mediálních) vnímána implicite a jednostranně jako škodlivina;

2. Druhou př́činou byla slabá výzkumná produkce. Chyběl dostatečně „hustý“ empirický výzkum popisující reálnou edukaci. Znalost výzkumné metodologie byla nedostatečná. Konstatoval jsem tenkrát, že:

- pedagogicko-psychologický výzkum málo spolupracoval s ostatními pedagogickými vědami, trpěl určitou izolovaností a neotvíral témata na rozhraní (např. pedagogická psychologie byla klasickou aplikovanou psychologickou disciplínou);

- varoval jsem, že pedagogický výzkum je po r. 1990 znovu pojímán jako nástroj k prosazování modelů a norem (konečně) žádoucí podoby školy a edukace a snaží se vyhovět tzv. společenské potřebě. Různé „reformní" výkřiky sypané z rukávu (fragmenty „obrázků z ciziny“ a „Vzpomínek na vlastní minulost“) měly být jen ilustrovány či dokládány výzkumem. Pedagogickému výzkumu hrozila opět služebná role ilustrace či kolorování načrtnutých vzorů.

- A konečně, domníval jsem se, že pedagogický výzkum musí začít stavět mosty mezi výzkumníky a učiteli, tj. legitimizovat jejich zkušenost a řeč, vtahovat je do výzkumu a do zájmu o výzkum.

Na závěr jsem vyslovil tři přání. Za prvé, aby pedagogický výzkum poskytoval co nejméně zkreslující zrcadlo chování a aspirací všech aktérů vzdělávání a dění ve školách. Za druhé, aby jim poskytoval řeč, která by šla za povrchní ideologickou doxu a umožnila jim jinak artikulovat nebo hlouběji porozumět situacím výchovy. A konečně, aby poznatky, metody a modely vzešlé z pedagogického výzkumu sloužily školské politice k dobrým a odpovědným rozhodnutím.

Co mohu po dvaceti letech konstatovat? Moji stručnou odpověd' vymezenou tímto malým prostorem lze shrnout do pěti bodů.

1. Empirický pedagogický výzkum se významně rozvinul jak co do objemu, tak co do kvality. Vzniklo několik výzkumných center a na řadě dalších pracovišt' se objevují dílčí kvalitní výzkumy. Roste počet časopisů, monografií, učebnic a vyzdvihnout je třeba také vznik Pedagogické encyklopedie. To vše je rozhodně pokrokem. 
2. Dlužno však konstatovat, že za empirickým výzkumem zaostává výzkum teoretický. Nejenževyužíváme málo filozofické, politologické, sociologické ad. poznatky pro pochopení vysvětlujících rámců našich výsledků. Jako taken for granted bereme i agendu neoliberálního způsobu vlády, místo abychom ji kriticky přezkoumávali (na mysli mám ideologii vzdělání pro konkurenceschopnost, kompetencí, excelence a dalších témat.

3. Pedagogický výzkum se nedokázal dostatečně prosadit ve školské politice - a není to jenom chyba politiků, i když posledních šest let tvoří jednu z nejčernějších etap řízení národního vzdělávání. Zdá se, že u nás stále chybí zprostředkující článek v podobě implementačního výzkumu, který by dokázal převádět poznatky základního i aplikovaného výzkumu do řeči prováděcích opatření.

4. Dodnes bohužel ideologické recidivy typu „vyučujme tvořivosti a myšlení místo biflování“, „zaměřme se na kompetence, ne na poznatky“ apod. nevyvolávají téměř žádnou reakci seriózní výzkumné obce. I přes existenci výzkumných důkazů, které řadu těchto klišé vyvracejí (jako jsou např práce o vztahu pracovní a dlouhodobé paměti při učení řešením problémů). Podobně žádnou reakci nevyvolaly jednotlivé zprávy nebo výzkumy ekonomů přinášející např. absurdní predikce výnosů přírůstku výsledků v šetřeních PISA za 50 let a vyjádřených v procentech růstu HDP.

5. Konečně, čelíme novému nebezpečí: absence tzv. kumulativního efektu našeho poznání se ještě posiluje pod vlivem současné vykazovací éry. Poněkud vyhroceně bychom ho mohli vyjádřit následovně: nikdo skoro nic nečte, zato všichni pořád publikují. Ono staré publish or perish se v době neoliberální instrumentality změnilo na „publikuj úplně nejvíc, jinak zhyneš".

Přeji nám do dalších desetiletí, abychom dokázali v budoucnu zůstat kritickými badateli a nestali se služebnými experty. 